\title{
Genetic and epigenetic changes in malignant cells of tumors of urogenital organs
}

\author{
V. V. Gordiyuk
}

Institute of Molecular Biology and Genetics NAS of Ukraine 150, Akademika Zabolotnogo str., Kyiv, Ukraine, 03680

vasilij_gordiyuk@yahoo.com

\begin{abstract}
More than $90 \%$ of human malignant neoplasms are presented by epithelial tumors. Cancer of urogenital organs is a serious problem because of wide spread of disease and high mortality rates. Tumorogenesis is associated with different defects of genetic apparatus of cells as well as epigenetic factors (DNA methylation disorders, chromatin reorganizations in processes of histones modifications, regulation of gene expression with small non-coding RNAS). In this review we analyzed genetic and epigenetic changes in the urogenital tumors.
\end{abstract}

Keywords: cancer of urogenital organs, modifications of histones, DNA methylation, oncogenes, mutations.

Tumor (neoplasia) is defined as abnormal overgrowth of tissue with hereditary ability to unlimited and uncontrolled growth. More than $90 \%$ of human malignant neoplasms $(\mathrm{MN})$ are presented by tumors of epithelial origin [1].

Most of such tumors appear in urogenital organs. It is difficult to cover all nosological $\mathrm{MN}$ forms of urogenital organs in a single review. Therefore we attempted to analyse genetic and epigenetic alterations in renal, prostate, cervical, and ovarian cancer.

The loss of adhesive functions and formation of invasive phenotype are recognized as crucial factors for malignization of epithelial cells. The tissue dedifferentiation and epithelial-mesenchymal transition are important events for the progression of epithelial tumors as well. Moreover, various types of cancer are characterized by dysfunction of tissue specific transcription factors, candidates for gene suppressors of tumors, i.e., hepatocytes nuclear factor (HNF), and in addition activation of oncogenes, immortalization, apoptosis suppression, and neoangiogenesis [2].

The structure of malignant tumor and its functional relationship with microenvironment are complicated. It shows itself as a distinct organ, able to use normal cells for angiogenesis, metastatic niche formation, and defence against immune response.

International TNM-classification of $\mathrm{MN}$ is currently accepted: $\mathrm{T}$ (tumor) - proliferation of primary tumor; $\mathrm{N}$ (nodes) - invasion in regional lymph nodes; M (metastases) - presence of metastases [3].

Cancer as a cause of death possesses the second place, it follows closely cardiovascular diseases. In 2006, the MN morbidity rate in Ukraine was 342 cases per 100,000 population with a tendency to increase, whereas mortality rate was 188 cases per 100,000 population [4]. 
The structure of morbidity/mortality in Ukraine is represented by such forms of urogenital cancer as (\%): prostate $-7.4 / 6$; renal (in men) - 3.5/3.1; cervical 8.1/6.2; ovaries $-6.3 / 4.9$ [4].

Among ovarian carcinomas, the predominant forms by histological structure are serous ( about 80\%), endometrioid, mucosa, and clear cell tumors, which are the most aggressive types. The problem of ovarian cancer (OC) is considered to be one of the most important in current oncology due to peculiarities of etiology, pathogenesis and clinical course of the tumor development in this organ that leads to late diagnosis and poor survival of patients. OC ranks the third rate in the detection among all oncoginecological diseases in Ukraine (12.7 \% of all MN among women aged 15-29 years) and the first in mortality rate. The highest mortality $(8.3 \%)$ is observed among women aged 30-54 years [4].

Squamous cell cancer is about $80 \%$ of cervical malignant tumors, whereas adenocarcinomas and clear cell adenocarcinomas are not common. The papilloma virus infection contributes to the formation of both benign and malignant tumors. In the latter case, the disturbance of cervical epithelium structure occurs, preceding the development of invasive cancer. Cervical cancer (CC) has the second position in Ukraine, and the highest morbidity and mortality rates were registered among women aged 15-29 years (15.2 $\%$ of all $\mathrm{MN})$ and 30-54 years (11.7 \%) correspondently [4].

Renal carcinoma (RC) possesses the 10-th place among the most widespread forms of cancer that is approximately $3 \%$ of all oncological diseases. Clear cell $\mathrm{RC}$, granular cell $\mathrm{RC}$, spindle cell $\mathrm{RC}$, and columnar-cell renal cancers are distinguished. In Ukraine, the incidence of renal cancer in men aged $30-54$ years reaches $5.3 \%$ of all $\mathrm{MN}$, and the number of patients with renal cell carcinoma (RCC) is annually increasing [4].

Adenocarcinomas are about $95 \%$ of all prostatic cancers (PC), whereas transitional cell cancer and squamous cell cancer are less common. The substantial percentage of biopsies performed in patients with suspected oncopathology of this organ is defined as prostatic intraepithelial neoplasia (PIN). PIN is generally characterized by preservation of basal membrane integrity. The part of PC reaches $12 \%$ of malignant tumors among men. During last years this disease is being diagnosed at younger age [4].

Therefore, urogenital cancer remains a serious problem in Ukraine due to its abundance and high mortality rate. The investigation of cancerogenesis peculiarities of given nosological $\mathrm{MN}$ forms on molecular level may help for their early diagnostics.

Mutations and chromosomal rearrangements in urogenital cancer. Basic study of cellular and molecular mechanisms of oncogenesis has revealed several genetic and epigenetic alterations that accompany the process of tumor development [5] (see Figure).

Various damages of cell genetic apparatus (somatic mutations, chromosomal aberrations) are known to be a base of malignant cell transformation. This may result in conversion of protooncogenes into oncogenes, shutdown of suppressive genes as well as dysfunction of the DNA post-replicative reparation system. Structural alterations of genes appear due to external or internal cancerogenic impacts. Additionally, high malignization risk is thought to be determined by inherent genotype damages.

The occurrence of certain chromosomal aberrations and mutations can correlate with several MN forms. Leukemias and lymphomas are mainly characterized by translocations, in particular, those of $m y c$ - gene [6]. However, the current data also indicate a role of translocations in the induction of solid tumors, including those of urogenital tract. Thus, the fused genes PSF-TFE3 and TMPRSS2-ERG were found to appear in renal cancer [7] and PC [8] correspondently. The fused oncogenes encode chimeric proteins (transcription factors, proteinkinases). The sites of chromosome translocations in tumors proved to be associated with Z-DNA domains, and in $95 \%$ of cases a correlation between genetic instability and Z-DNA is observed in mammals [9].

Amplifications are known to be caused by DNA replication disorder. They can be accompanied by DNA recombination and consequently its irregular distribution between daughter cells [10]. High amplification level of certain sites causes the formation of so-called pseudo-chromosomes (double-minute chromosome) [11]. Amplification of myc oncogene is 


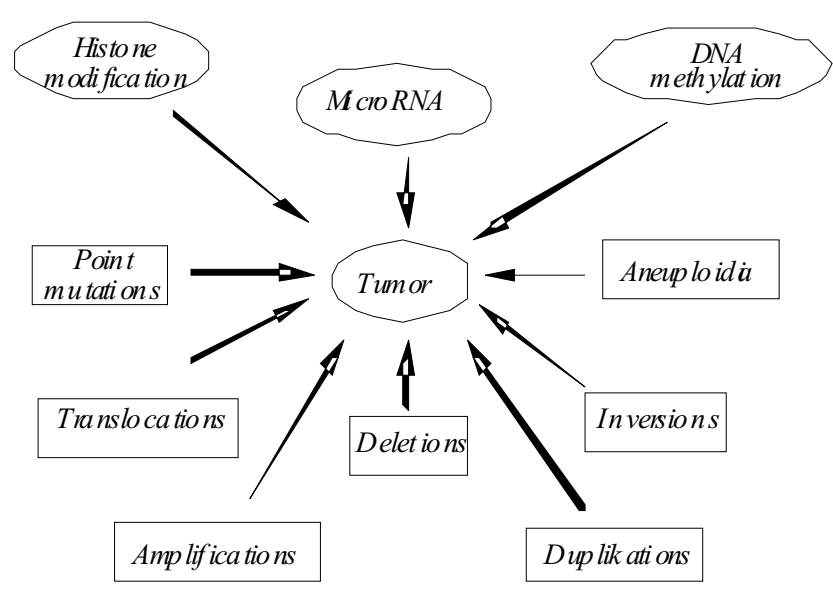

Epigenetic and genetic tumor induction factors

found in various cancer types [12], while amplification of Notch 3 and PIK3CA genes is frequent in OC [13]. Amplifications along with point mutations of EGFR gene are typical for serous ovarian cancer [14]. It is worth noticing that amplification of multiple drug resistance $(M D R)$ genes advances the tumor resistance to anticancer drugs [15].

Aneuploidia appears as a result of dysfunction of cell division control and may be a cause of significant increase in chromosome number of tumor cells. In particular, cervical cancer is associated with aneuploidia of the both 3-rd and 17-th chromosomes [16]. At OC, the aneuploidic cell formation is related to the loss of GATA6 transcription factor expression with participation of microRNA [17].

Another few chromosomal rearrangements, such as inversion, deletions, insertions, and duplications, are rather frequent in carcinomas. For example, inversion of pericentromere region of the 9-th chromosome is associated with OC [18]. Also, a loss of function of imprinted gene NOEY2 of the RAS family due to the deletion of active allele is a sign of ovarian cancer [19]. The involvement of Alu-repeats in duplication of the 13-th exon of BRCA1 gene was revealed [20]. Moreover, Alu-repeats themselves were shown to contain insertion mutations in OC [21].

Various chromosome aberrations are likely to appear due to disorder of general regulative mechanism supporting normal chromosome segregation [10].

Point mutations of $R A S$ oncogene acompany many $\mathrm{MN}$ [22]. Inactivation of a key gene, tumor growth suppressor $p 53$, is induced by DNA recombination, aneuploidia, deletions as well as by point mutations. Mutations of $p 53$ gene were observed in many types of human tumors including urogenital cancer [[23]; mutations of $B R C A 2$ were found, in particular, in ovary cancer [[24]; mutations of BRCAI are linked with a block of stem cells differentiation and an increase of their population [25].

Genome instability is hereby considered to be the main cause of the tumor induction and development. It is manifested by progressive accumulation of mutations affecting basic vital functions of cells [26]. An important factor of cell transformation is currently believed to be the autocrine activation of cell proliferation resulting from the interaction of oncogene product with appropriate receptor located on the cell membrane or inside the cell [27].

However, it is necessary to keep in mind that an important role in tumor growth belongs to the microenvironment, whose components are in complex relationship with cancer cells.

Epigenetic alterations in urogenital cancer. Besides genetic aberrations, epigenetic factors (chromatin remodelling under histone modifications, regulation of gene expression with non-coding small RNAs, DNA methylation disorder) make a significant contribution to cancerogenesis that leads to alterations in the transcription of vast number of genes.

Histone modifications. Epigenetic mechanisms of realization of histone code act on the chromatin level thus programming the development of organism. Replication, recombination, reparation, and transcription are all controlled by the changes in structure and spatial organization of chromatin. It is well known that histones are conservative proteins. Nevertheless, there is a wide set of their covalent modifications determining the gene functional state. The role of Z-DNA in modulation of chromatin structure and posttranslational modifications of histone was also shown [28]. In turn, histone modifications can serve as a signal for DNA methylation [29].

A level of histone acetylation, which is reversible Lys modification in $\mathrm{N}$-terminal domains of core histones, indicate a possibility of cancerogenesis. Thus, estrogen receptor (ER) initiates histone acetylation and activation of expression of genes taking 
part in apoptosis regulation, immortalization, angiogenesis, and invasion. In contrast, BRCA1 provides histone deacetylation and ER ubiquitinization thereby blocking expression of downregulated genes [30]. In general, cancer cells are characterized by trimethylation of lysine 20 in histone $\mathrm{H} 4$ and loss of acetylation of lysine 16 [31]. Histone methyltransferases are involved in the tumor development (EZH2 - enhancer of zeste homolog 2) and suppression (RIZ1 - retinoblastoma protein-interacting zing finger protein) [32]. EZH2 was demonstrated to play a role in DNA methylation due to DNA-methyltransferases involvment and deacetylation of histones (in synergism with HDAC 1 and 2) [33].

Increase in HDAC activity (determined by histone deacetylases) is associated with tumor progression in solid MN including oncopathologies of urogenital organs [34]. Thus, expression of HDAC1 and HDAC2 significantly increases at dysplasia and cervical carcinoma. Moreover, E7 oncoprotein of herpes virus appears to be a component of enzyme complexes HDAC 1 and 2 [35].

HDAC1 high level correlates with unfavourable prognosis in endometrial carcinoma [36], while loss of trimethylation of lysine 27 in histone $\mathrm{H} 3$ is considered as a prognostic marker in ovarian cancer [37]. Histone acetyltransferase (HAT) Hbol promotes DNA replication, and overexpression of its gene is observed in the reviewed pathology [38].

It was shown that activation of HDAC3 and HDAC6 represses expression of Aurora A, a negative regulator of cell cycle, thus involved in renal cancer development [39]. In this case, overexpression of HDAC 1 and 2 is also observed [34]. Hypoxia inducible factor (HIF) provides histone demethylation through activation of histone demethylases (JMJD1 A and others) stimulating induction of renal carcinoma under hypoxia [40].

Demethylation of lysine 9 in histone $\mathrm{H} 3$ (H3K9me2) takes place in PC and RC and correlates with an increase in DNA repeats level. Dimethylation of lysine 4 and acetylation of lysine 18 in histone $\mathrm{H} 4$ also increase risk of prostatic cancer [41]. On the contrary, protein MCP30 promotes HDAC1 inhibition and histones $\mathrm{H} 3$ and $\mathrm{H} 4$ acetylation, thus suppressing the development of oncological disease [42]. Trimethylation profile of lysine 4 and lysine 27 in histone H3 [43] together with histone H3 phosphorilation [44] are considered as a prognostic factor at PC.

Revealing specific samples (signature) of acetyl and methyl histone labels is thought to be promising approach for diagnostics of urogenital tumors and prognosis of their development.

$R N A$-associated regulation of expression. The next important level of epigenetic regulation is provided by non-coding microRNA via binding with complementary site of appropriate mRNA resulting in its degradation and translation block. MicroRNAs are able to control the processes of histone modification and DNA methylation. Human genome contains over thousand of microRNA genes. Aberrant production of microRNAs is observed in tumors. MicroRNA sets are detected using recent microchip technologies [45].

It is known that malignization of epithelial cells is promoted by microRNA-205, whose expression is repressed by microRNA-184 [46]. MicroRNA-378 is capable of blocking caspase-3 activity and as a result promotes cancer cell survival and angiogenesis. Besides, it inhibits expression of the gene- suppressor of tumor growth FUS1 (fused in sarcoma) [47].

Changes in microRNA content and expression in MN of urogenital organs are being extensively studied. Thus, methylation of promotor of microRNA-34a gene inducing inactivation of the suppressor of tumor growth, which also promotes apoptosis and cell differentiation, is found in various malignant tumors including prostatic cancer [48].

The development of aggressive forms of solid tumors (in particular prostatic ones) is associated with the loss of expression of microRNA-449, the suppressor of histone methyltransferase EZH2 that consequently leads to survival and metastasis of cancer cells [32].

A decrease in microRNA-34a expression, that mainly targets HDAC1, is observed in prostatic cancer [49]. Over 50 microRNAs associated with the prostate malignization have been already recognized [45].

The blocking of microRNA-34a expression through the promotor hypermethylation is observed at $\mathrm{KC}$ as well [48]. Simultaneous presence of both 
microRNA-141 and microRNA-156 is also observed in $97 \%$ of samples of clear cell renal carcinoma [50].

Normally, ovarian microRNAs regulate oocyte maturation [51], however they can also be involved in $\mathrm{MN}$ formation [52]. In particular, the oncogene microRNA-21 expression is elevated due to DNA demethylation in ovarian cancer. The suppressor protein BRCA1 is targeted by microRNA-212 in serous carcinomas [53]. Hypermethylation of microRNA-129-2, the negative regulator of SOX-4 oncogene, correlating with microsatellite instability, is observed in endometrial cancer [54].

It was shown that the papilloma E6 viral protein leads to destabilization of $\mathrm{p} 53$, the transactivator of suppressor microRNA34a, resulting in consequent inactivation of the latter in cervical cancer [55].

Methylation of tumor suppressing microRNA-1 gene, which in turn targets histone deacetylase HDAC4, occurs with the aid of DNMT1 [56].

Since microRNAs fulfil both positive and negative regulation of tumor development, their expression profile is often associated with diagnosis, stages, progression, oncopathology prognosis, and therapeutic response. The perspectives of gene therapy are associated with the usage of microRNA for inactivation of oncogenic signal pathways or genes involved at cancerogenesis [57].

Alterations of DNA methylation status. Methylation provides X-chromosome inactivation, imprinting, regulation of tissue-specific gene expression, and control on genome stability. Methylation block is linked to embryogenesis arrest and apoptosis, while changes of methylation status with oncogenesis [58].

$C p G$-islands and gene transcription. In mammals, most 5'-methylcytosines are concentrated in 5 '-CpG-3 '-dinucleotides. In CpG-islands frequency of $\mathrm{CpG}$-dinucleotides is 5 times more comparing to other DNA fragments. These regions occupy 1-2 \% of genome and have average size of $1,000 \mathrm{bp}$. [59]. $\mathrm{CpG}$ in these islands normally are not methylated except imprinted genes, whereas most CpG-dinucleotides outside the islands are methylated [60]. CpG-islands are distinguished by a high content of guanine and cytosine ( $\mathrm{G}+\mathrm{C}$ exceeds $60 \%)$. Over $80 \%$ of NotI-sites are linked with $\mathrm{CpG}$-rich regions. The general feature of such islands is their localization in 5'-sites of genes, in regulative sequences or in the first exon [61].

Due to the structural homology between 5'-methylcytosine and thymine, methylation of cytosine residues can be accompanied with the formation of new transcription factor binding sites. This process affects transcription due to changes in binding efficacy of transcription factors with their regulatory sites on DNA molecule and the formation of transcriptionally inactive chromatin regions with participation of MeCP1 and MeCP2 proteins [62].

Methyl-DNA-binding proteins, containing methyl-binding domain (MBD), are capable of blocking TSG (tumor suppressor gene) transcription by interaction with their methylated promotors [63]. MBD1 protein, interacting with histone methyltransferase, is involved in the chromatin inactivation while MBD4 protein takes part in DNA reparation; its dysfunction promotes tumorogenesis [64]. An increased expression of $M B D 2$ gene correlates with its hypermethylation and progression of ovarian cancer, however, inverse relationship is observed in colorectal cancer [66].

Hypermethylation and urogenital cancer. Occurrence of $\mathrm{MN}$ in human is associated with imbalance of DNA methylation. Moreover, the correlation between aberrant methylation of CpG-islands and location of chromosomal breakage is observed in early periods of tumor development.

Methylation of promotor CpG-islands can inactivate both alleles of TSG, thus promoting malignization [67]. Besides, 5'-methylcytosine itself is able to induce mutation due to its instability. Structural proteins and transcription factors compete with methyltransferase for binding sites in CpG-islands. Therefore, such imbalance during cancerogenesis results in their aberrant methylation [68]. It was also shown that methylation of tumor-suppressing microRNAs was a prerequisite for metastasis [69].

It is important to note that an increase in the DNA-methyltransferase (DNMT) activity occurs as a result of p53 and Ras dysfunctions during cancerogenesis. DNMT1 promotor is activated by the product of $H$-ras gene, which is involved in mitogenic signal transferring. In addition, the DNMT1 $\mathrm{N}$-terminal domain is able to interact with histone 
deacetylases in protein complexes of transcription repression, tumor suppressor $\mathrm{Rb}$ (retinoblastoma protein), replicative fork protein PCNA (proliferating cell nuclear antigen), thus participating in the malignant transformation process [70].

Aberrant methylation of several TSG is revealed in urogenital tumors. Thus, methylation of $\mathrm{CpG}$-islands of the OPCML (opioid binding protein/cell adhesion molecule-like) promotor, with the decrease of its expression was observed in cervical cancer [71]. So, $O P C M L$ in fact is a candidate in TSG. It was also demonstrated the decrease in the expression level of corresponding protein as a result of CADM (cell adhesion molecule) gene methylation [72], while epigenetic shutdown of DKK1 (dickkopf homolog 1) was revealed in the cell lines of cervical cancer [73].

Ovarian cancer is associated with aberrant methylation of FANCF (Fanconi anemia, complementation group F) gene. Its product is known to play a crucial role in DNA reparation [74]. Stratifin

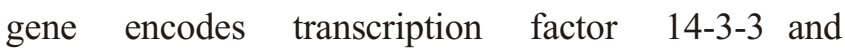
contributes to genome integrity through mitosis control. All of its $17 \mathrm{CpG}$-islands are methylated in OC [75].

In ovarian cancer, inactivation of TSG $A R H I$ (anaplasia Ras homologue member 1), PEG3 (paternally expressed gene 3 ), and $O P C M L$, occurs as a result of heterozygosity loss and promotor methylation $[76,77]$. Promotor methylation was also revealed for $D A P K$ (dystrophin) [78], DLEC1 (the deleted in lung and oesophageal cancer) [79], RASSF1A (RAS-association domain family member 1) in OC [80].

Hypermethylation also exists in PC [81], while inactivation of gene-suppressor $p 16$ by promotor hypermethylation occurs in renal carcinoma [82]. Epigenetic inactivation of oncosuppressor gene BTG3 (B-Cell translocation gene 3 ) is observed in prostatic and renal cancers. Such inactivation by promotor hypermethylation and histone modifications (acetylation level changes of lysine in histone H3) is also documented for the negative regulator of the cell cycle $[83,84]$.

Methylation of $O P G$ (osteoprotegerin) gene was revealed in cells of renal, ovarian and cervical carcinomas in parallel with the alteration of histone $\mathrm{H} 3$ methylation: elevation of lysine 27 and decrease of lysine 4 methylation [85].
Investigation of gene hypermethylation in tumors allows us to establish consistent patterns associated with disease progression or histological features. For example, aberrant promotor methylation of genes 14-3-3 $\sigma$, TMS1 (target of methylation induced silencing), WT1 (wilms tumor suppressor 1) is often observed in clear cell ovarian carcinoma [86-88], whereas hypermethylation of RASSF1A, APC (adenomatosis polyposis coli) and GSTPI (glutathione S-transferase 1) is only revealed in invasive ovarian carcinoma unlike the tumors with low malignization potential (LMP) [89]. Methylation of promotors of $A P C$ and GSTP1 genes is considered to be prognostic marker for patients' survival [90].

Hypomethylation and cancer of urogenital system. In parallel with hypermethylation of CpG-islands in promotor regions of genes extensive hypomethylation takes place in genome of cancer cells [91] that is confirmed by evaluation of 5 '-methylcytosine content in DNA [92]. A significant amount of hypomethylated genes including such oncogenes as CMYC and HRAS is observed in primary cancer [93].

Hypomethylation of TUBB3 (tubulin beta, class 3) gene leads to its overexpression that provokes malignization and resistance to chemotherapy of ovarian cancer [94]. This pathology is also characterized by hypomethylation of SERPINB5 (serpin peptidase inhibitor, class 5) [95], SNCG (synuclein, gamma) [96] and CLDN4 (claudin 4) [97]. Elevation of hypomethylation simultaneously with increase of malignization degree is noted for several genes in ovarian and cervical cancers [65]. Therefore, DNA hypomethylation could be considered as a prognostic marker. Hypomethylation in tumor cells can cause transcriptional activity of mobile elements of genome, which in turn activate the oncogene transcription. Demethylation of promotors and expression of LINEs (long interspersed nuclear elements) are observed in various types of sporadic cancer [98]. Demethylation of satellite DNA is also found in cancer [93]. Thus, in normal somatic cells, pericentromeric heterochromatin regions on the 1-st chromosome are characterized by a high methylation status. Meanwhile, they appear to be demethylated in ovarian cancer. Moreover, more extensive hypomethylation of satellite DNA was shown in serous 
and endometrioid ovarian carcinomas in comparison with mucinose one [99].

Total hypomethylation of constitutive heterochromatin can be accompanied by chromosomal translocations and aneuploidia at cancerogenesis.

Summarizing the data described herein, we can make the conclusion about interrelation not only between genetic and epigenetic mechanisms of gene expression control but also between various levels of epigenetic regulation.

Complexity and variability of epigenetic changes at $\mathrm{MN}$ are reflected in the current ideas on the existence of common signaling network ("functional network of human epigenetic silencing factors"). In particular, histone deacylase 1, DNA-methyltransferase 3a, histone lysine methyltransferase, and histone chaperone CHAF1A are involved in the network. This opens up new perspectives for the elucidation of molecular mechanisms of tumor genesis and for the selection of the most important targets at cancer therapy including oncopathologies of urogenital tracts.

\section{B. В. Гордиюк}

Генетические и эпигенетические изменения

в клетках злокачественных опухолей урогенитальной сферы человека

Резюме

Более 90 \% злокачественных новообразований у человека имеют эпителиальное происхождение. Рак органов урогенитальной сферы представляет серьезную проблему в связи с его распространенностью и высоким показателем смертности. Образование опухолей обусловлено различными повреждениями генетического аппарата клетки, а также эпигенетическими факторами (пе-рестройки хроматина при модификаџиях гистонов, регуляиия экспрессии генов с участием некодирующчих малых РНК, нарушение процессов метилирования ДНК). В обзоре проанализированы генетические и эпигенетические изменения при раке органов урогенитальной сферы.

Ключевые слова: рак урогенитальной сферы; модификации гистонов, метилирование ДНК, онкогены, мутации.

\section{B. В. Гордіюк}

Генетичні та епігенетичні зміни у клітинах злоякісних пухлин урогенітальної сфери людини

Резюме

Більше $90 \%$ злоякісних новоутворень людини становлять пухлини епітеліального походження. Рак органів урогенітальної сфери є значною проблемою через свою розповсюдженість $і$ високий показник смертності. Виникнення пухлин обумовлено різними пошкодженнями генетичного апарату клітини, а та- кож епігенетичними факторами (перебудови хроматину при модифікаціях гістонів, регулячія експресії генів за участі некодуючих малих РНК, порушення прочесів метилювання ДНК). В огляді проаналізовано генетичні та епігенетичні зміни при раку органів урогенітальної сфери.

Ключові слова: рак урогенітальної сфери, модифікації гістонів, метилювання ДНК, онкогени, мутаціï.

\section{REFERENCES}

1. Miller S., Lavker R. M., Sun T. T. Interpreting epithelial cancer biology in the context of stem cells: Tumor properties and therapeutic implications // Biochim. Biophys. Acta.- 2005.1756, N 1.-P. 25-35.

2. Lazarevich N. L., Fleishman D. I. Tissue-specific transcription factors in progression of epithelial tumors // Biochemistry.-2008.-73, N 5.-P. 573-591.

3. AJCC Cancer Staging Handbook.-New-York: Springer, 2002.-423 p.

4.Cancer in Ukraine, 2004-2005. Ukrainian cancer registry statistics, 2006 // Bull. of national cancer registry of Ukraine (engl.) / Ed. C. O. Shalimov.-Kyiv, 2006.

5. Negm R. S., Verma M., Srivastava S. The promise of biomarkers in cancer screening and detection // Trends Mol. Med.2002.-8, N 6.-P. 288-293.

6. Huh Y. O., Lin K. I., Vega F., Schlette E., Yin C. C., Keating M. J., Luthra R., Medeiros L. J., Abruzzo L. V. MYC translocation in chronic lymphocytic leukaemia is associated with increased prolymphocytes and a poor prognosis // Br. J. Haematol.- 2008.-142, N 1.-P. 36-44.

7. Chang I. W., Huang H. Y., Sung M. T. Melanotic Xp11 translocation renal cancer: a case with PSF-TFE3 gene fusion and up-regulation of melanogenetic transcripts // Amer. J. Surg. Pathol.-2009.-33, N 12.-P. 1894-1901.

8. Clark J. P., Cooper C. S. ETS gene fusions in prostate cancer // Nat. Rev. Urol.-2009.-6, N 8.-P. 429-439.

9. Wang G., Vasquez K. M. Z-DNA, an active element in the genome // Front. Biosci.-2007.-12.-P. 4424-4438.

10. Stark G. R. Regulation and mechanisms of mammalian gene amplification // Adv. Cancer Res.-1993.-61.-P. 87-113.

11. Kamath A., Tara H., Xiang B., Bajaj R., He W., Li P. Doubleminute MYC amplification and deletion of MTAP, CDKN2A, CDKN2B, and ELAVL2 in an acute myeloid leukemia characterized by oligonucleotide-array comparative genomic hybridization // Cancer Genet. Cytogenet.-2008.183, N 2.-P. 117-120.

12. Hansel D. E., Swain E., Dreicer R., Tubbs R. R. HER2 overexpression and amplification in urothelial carcinoma of the bladder is associated with MYC coamplification in a subset of cases // Amer. J. Clin. Pathol.-2008.-130, N 2.-P. 274-281.

13. Nakayama K., Nakayama N., Jinawath N., Salani R., Kurman R. J., Shih Ie. M., Wang T. L. Amplicon profiles in ovarian serous carcinomas // Int. J. Cancer.-2007.-120, N 12.-P. 26132617.

14. Lassus H., Sihto H., Leminen A., Joensuu H., Isola J., Nupponen N. N., Butzow R. Gene amplification, mutation, and protein expression of EGFR and mutations of ERBB2 in serous ovarian carcinoma // J. Mol. Med.-2006.-84, N 8.-P. 671681.

15. Кио M. T. Roles of multidrug resistance genes in breast cancer chemoresistance // Adv. Exp. Med. Biol.-2007.-608.P. 23-30. 
16. Olaharski A. J., Sotelo R., Solorza-Luna G., Gonsebatt M. E., Guzman P., Mohar A., Eastmond D. A. Tetraploidy and chromosomal instability are early events during cervical carcinogenesis // Carcinogenesis.-2006.-27, N 2.-P. 337-343.

17. Capo-chichi C. D., Cai K. Q., Testa J. R., Godwin A. K., XuX. $X$. Loss of GATA6 leads to nuclear deformation and aneuploidy in ovarian cancer // Mol. Cell Biol.-2009.-29, N 17.P. 4766-4777.

18. Yasuhara T., Okamoto A., Kitagawa T., Nikaido T., Yoshimura T., Yanaihara N., Takakura S., Tanaka T., Ochiai K., Ohtake $Y$. FGF7-like gene is associated with pericentric inversion of chromosome 9, and FGF7 is involved in the development of ovarian cancer // Int. J. Oncol.-2005.-26, N 5.P. 1209-1216.

19. Li A. J., Karlan B. Y. Genetic factors in ovarian carcinoma// Curr. Oncol. Rep.-2001.-3, N 1.-P. 27-32.

20. Yap K. P., Ang P., Lim I. H., Ho G. H., Lee A. S. Detection of a novel Alu-mediated BRCA1 exon 13 duplication in Chinese breast cancer patients and implications for genetic testing // Clin. Genet.-2006.-70, N 1.-P. 80-82.

21. Montagna M., Santacatterina M., Torri A., Menin C., Zullato D., Chieco-Bianchi L., D'Andrea E. Identification of a $3 \mathrm{~kb}$ Alu-mediated BRCA1 gene rearrangement in two breast/ ovarian cancer families // Oncogene.-1999.-15, N 28P. 4160-4165.

22. Plesec T. P., Hunt J. L. KRAS mutation testing in colorectal cancer // Adv. Anat. Pathol.-2009.-16, N 4.-P. 196-203.

23. Greenblatt M. S., Bennett W. P., Hollstein M., Harris C. C. Mutations in the p53 tumor suppressor gene: clues to cancer etiology and molecular pathogenesis // Cancer Res.-1994.54, N 18.-P. 4855-4878.

24. Hughes D. J. Use of association studies to define genetic modifiers of breast cancer risk in BRCA1 and BRCA2 mutation carriers // Fam. Cancer.-2008.-7, N 3.-P. 33-44.

25. Vermeulen L., Sprick M. R., Kemper K., Stassi G., Medema J. $P$. Cancer stem cells - old concepts, new insights // Cell Death. Differ.-2008.-68, N 4.-P. 1213-1220.

26. Loeb L. A., Bielas J. H., Beckman R. A. Cancers exhibit a mutator phenotype: clinical implications // Cancer Res.-2008.68, N 10.-P. 3551-3557.

27. Groen R. W., Oud M. E., Schilder-Tol E. J., Overdijk M. B., ten Berge D., Nusse R., Spaargaren M., Pals S. T. Illegitimate WNT pathway activation by beta-catenin mutation or autocrine stimulation in T-cell malignancies // Cancer Res.-2008.-68, N 17.-P. 6969-6977.

28. Liu H., Mulholland N., Fu H., Zhao K. Cooperative activity of BRG1 and Z-DNA formation in chromatin remodeling // Mol. Cell Biol.-2006.-26, N 7.-P. 2550-2559.

29. Jenuwein T., Allis C. D. Translating the histone code// Science.-2001.-293, N 5532.-P. 1074-1080.

30. Ma Y., Fan S., Hu C., Meng Q., Fuqua S. A., Pestell R. G., Tomita Y. A., Rosen E. M. BRCA1 regulates acetylation and ubiquitination of estrogen receptor-\{alpha\} // Mol. Endocrinol.-2010.-24, N 1.-P. 76-90.

31. Gibbons R. J. Histone modifying and chromatin remodeling enzymes in cancer and dysplastic syndromes // Hum. Mol. Genet.-2005.-14, N 1.-P. 85-92.

32. Varambally S., Cao Q., Mani R.-Sh., Shankar S., Wang X., Ateeq B., Laxman B., Cao X., Jing X., Ramnarayanan K., Brenner J. Ch., Yu J., Kim J. H., Han B., Tan P., KumarSinha Ch., Lonigro R. J., Palanisamy N., Maher Ch., Chinnaiyan A. M. Genomic loss of microRNA-101 leads to overexpression of histone methyltransferase EZH2 in cancer // Science.-2008.-322, N 5908.-P. 1695-1699.
33. Simon J. A, Lange C. A. Roles of the EZH2 histone methyltransferase in cancer epigenetics // Mutat. Res.-2008.-647, N 1-2.-P. 21-29.

34. Fritzsche F. R., Weichert W., Ruske A., Gekeler V., Beckers T., Stephan C., Jung K., Scholman K., Denkert C., Dietel M., Kristiansen $G$. Class I histone deacetylases 1, 2 and 3 are highly expressed in renal cell cancer // BMC Cancer.-2008.-8.P. 381.

35. Lin Z., Bazzaro M., Wang M. C., Chan K. C., Peng S., Roden $R$. B. Combination of proteasome and HDAC inhibitors for uterine cervical cancer treatment // Clin. Cancer Res.-2009.15, N 2.-P. 570-577.

36. Weichert W., Denkert C., Noske A., Darb-Esfahani S., Dietel M., Kalloger S. E., Huntsman D. G., Kobel M. Expression of class I histone deacetylases indicates poor prognosis in endometrioid subtypes of ovarian and endometrial carcinomas // Neoplasia.-2008.-10, N 9.-P. 1021-1027.

37. Wei Y., Xia W., Zhang Z., Liu J., Wang H., Adsay N. V., Albarracin C., Yu D., Abbruzzese J. L., Mills G. B., Bast R. C. $J r$., Hortobagyi G. N., Hung M. C. Loss of trimethylation at lysine 27 of histone $\mathrm{H} 3$ is a predictor of poor outcome in breast, ovarian, and pancreatic cancers // Mol. Carcinogen.2008.-47, N 9.-P. 701-706.

38. Iizuka M., Takahashi Y., Mizzen C. A., Cook R. G., Fujita M., Allis C. D., Frierson H. F. Jr., Fukusato T., Smith M. M. Histone acetyltransferase Hbo 1: catalytic activity, cellular abundance, and links to primary cancers // Gene.-2009.-436, N 12.-P. 108-114.

39. Cha T. L., Chuang M. J., Wu S. T., Sun G. H., Chang S. Y., Yu D. S., Huang S. M., Huan S. K., Cheng T. C., Chen T. T., Fan P. L., Hsiao P. W. Dual degradation of aurora A and B kinases by the histone deacetylase inhibitor LBH589 induces G2-M arrest and apoptosis of renal cancer cells // Clin. Cancer Res.2009.-15, N 3.-P. 840-850.

40. Krieg A. J., Rankin E. B., Chan D., Razorenova O., Fernandez S., Giaccia A. J. Regulation of the histone demethylase JMJD1A by HIF-1 \{alpha\} enhances hypoxic gene expression and tumor growth // Mol. Cell Biol.-2010.-30, N 1.-P. 344353.

41. Seligson D. B., Horvath S., McBrian M. A., Mah V., Yu H., Tze S., Wang Q., Chia D., Goodglick L., Kurdistani S. K. Global levels of histone modifications predict prognosis in different cancers // Am. J. Pathol.-2009.-174, N 5.-P. 16191628.

42. Xiong S. D., Yu K., Liu X. H., Yin L. H., Kirschenbaum A., Yao S., Narla G., Difeo A., Wu J. B., Yuan Y., Ho S. M., Lam Y.W., Levine A. C. Ribosome-inactivating proteins isolated from dietary bitter melon induce apoptosis and inhibit histone deacetylase- 1 selectively in premalignant and malignant prostate cancer cells // Int. J. Cancer.-2009.-125, N 4.-P. 774-782.

43. Ke X. S., Qu Y., Rostad K., Li W. C., Lin B., Halvorsen O. J., Haukaas S. A., Jonassen I., Petersen K., Goldfinger N., Rotter V., Akslen L. A., Oyan A. M., Kalland K. H. Genome-wide profiling of histone h3 lysine 4 and lysine 27 trimethylation reveals an epigenetic signature in prostate carcinogenesis // PLoS One.-2009.-4, N 3-P. e4687.

44. Zeng Y., Abdallah A., Lu J. P., Wang T., Chen Y. H., Terrian $D$. M., Kim K., Lu Q. delta-Catenin promotes prostate cancer cell growth and progression by altering cell cycle and survival gene profiles // Mol. Cancer.-2009.-10, N 8.-P. 19.

45. Porkka K. P., Pfeiffer M. J., Waltering K. K., Vessella R. L., Tammela T. L. J., Visakorpi T. MicroRNA expression profiling in prostate cancer // Cancer Res.-2007.-67, N 13P. 6130-6135. 
46. Yu J., Ryan D. G., Getsios S., Oliveira-Fernandes M., Fatima A., Lavker R. M. MicroRNA-184 antagonizes microRNA-205 to maintain SHIP2 levels in epithelia // Proc. Nat. Acad. Sci. USA.-2008.-105, N 49.-P. 19300-19305.

47. Lee D. Y., Deng Z., Wang C. H., Yang B. B. MicroRNA-378 promotes cell survival, tumor growth, and angiogenesis by targeting SuFu and Fus-1 expression // Proc. Nat. Acad. Sci. USA.-2007.-104, N 51.-P. 20350-20355.

48. Lodygin D., Tarasov V., Epanchintsev A., Berking C., Knyazeva T., Korner H., Knyazev P., Diebold J., Hermeking H. Inactivation of miR-34a by aberrant $\mathrm{CpG}$ methylation in multiple types of cancer // Cell Cycle.-2008.-7, N 16-P. 25912600.

49. Noonan E. J., Place R. F., Pookot D., Basak S., Whitson J. M., Hirata H., Giardina C., Dahiya R. miR-449a targets HDAC-1 and induces growth arrest in prostate cancer // Oncogene.2009.-28, N 14.-P. 1714-1724.

50. Jung M., Mollenkopf H. J., Grimm C., Wagner I., Albrecht M., Waller T., Pilarsky C., Johannsen M., Stephan C., Lehrach $H$., Nietfeld $W$., Rudel T., Jung K., Kristiansen G. MicroRNA profiling of clear cell renal cell cancer identifies a robust signature to define renal malignancy // J. Cell Mol. Med.-2009.-Feb 17. [Epub ahead of print].

51. Toloubeydokhti T., Bukulmez O., Chegini N. Potential regulatory functions of microRNAs in the ovary // Semin. Reprod. Med.-2008.-26, N 6.-P. 469-478.

52. Yang N., Kaur S., Volinia S., Greshock J., Lassus H., Hasegawa K., Liang S., Leminen A., Deng S., Smith L., Johnstone C. N., Chen X. M., Liu C. G., Huang Q., Katsaros D., Calin G. A., Weber B. L., Butzow R., Croce C. M., Coukos G., Zhang L. MicroRNA microarray identifies Let-7i as a novel biomarker and therapeutic target in human epithelial ovarian cancer // Cancer Res.-2008.-68, N 24.-P. 10307-10314.

53. Iorio M. V., Visone R., Di Leva G., Donati V., Petrocca F., Casalini P., Taccioli C., Volinia S., Liu C. G., Alder H., Calin G. A., Münard S., Croce C. M. MicroRNA signatures in human ovarian cancer // Cancer Res.-2007.-67, N 18.-P. 8699-8707.

54. Huang Y. W., Liu J. C., Deatherage D. E., Luo J., Mutch D. G., Goodfellow P. J., Miller D. S., Huang T. H. Epigenetic repression of microRNA-129-2 leads to overexpression of SOX4 oncogene in endometrial cancer // Cancer Res.-2009.69, N 23.-P. 9038-9046.

55. Wang X., Wang H. K., McCoy J. P., Banerjee N. S., Rader J. S., Broker T. R., Meyers C., Chow L. T., Zheng Z. M. Oncogenic HPV infection interrupts the expression of tumor-suppressive miR-34a through viral oncoprotein E6 // RNA.2009.-15, N 4.-P. 637-647.

56. Datta J., Kutay H., Nasser M. W., Nuovo G. J., Wang B., Majumder S., Liu C. G., Volinia S., Croce C. M., Schmittgen T. D., Ghoshal K., Jacob S. T. Methylation mediated silencing of MicroRNA-1 gene and its role in hepatocellular carcinogenesis // Cancer Res.-2008.-68, N 13.-P. 5049-5058.

57. Calin G. A., Croce C. M. MicroRNA signatures in human cancers // Nat. Rev. Cancer.-2006.-6, N 11.-P. 857-866.

58. Strathdee G., Davies B. R., Vass J. K., Siddiqui N., Brown R. Cell type-specific methylation of an intronic $\mathrm{CpG}$ island controls expression of the MCJ gene // Carcinogenesis.2004.-25, N 5.-P. 693-670.

59. Venter J. C., Adams M. D., Myers E. W., Li P. W., Mural R. J., Sutton G. G., Smith H. O., Yandell M., Evans C. A., Holt R. A., Gocayne J. D., Amanatides P., Ballew R. M., Huson D. H., Wortman J. R., Zhang Q., Kodira C. D., Zheng X. H., Chen L., Skupski M., Subramanian G., Thomas P. D., Zhang J., Gabor
Miklos G. L., Nelson C., Broder S., Clark A. G., Nadeau J., McKusick V. A., Zinder N., Levine A. J., Roberts R. J., Simon M., Slayman C., Hunkapiller M., Bolanos R., Delcher A., Dew I., Fasulo D., Flanigan M., Florea L., Halpern A., Hannenhalli S., Kravitz S., Levy S., Mobarry C., Reinert K., Remington K., Abu-Threideh J., Beasley E., Biddick K., Bonazzi V., Brandon R., Cargill M., Chandramouliswaran I., Charlab R., Chaturvedi K., Deng Z., Di Francesco V., Dunn P., Eilbeck K., Evangelista C., Gabrielian A. E., Gan W., Ge W., Gong F., Gu Z., Guan P., Heiman T. J., Higgins M. E., Ji R. R., Ke Z., Ketchum K. A., Lai Z., Lei Y., Li Z., Li J., Liang Y., Lin X., Lu F., Merkulov G. V., Milshina N., Moore H. M., Naik A. K., Narayan V. A., Neelam B., Nusskern D., Rusch D. B., Salzberg S., Shao W., Shue B., Sun J., Wang Z., Wang A., Wang X., Wang J., Wei M., Wides R., Xiao C., Yan C., Yao A., Ye J., Zhan M., Zhang W., Zhang H., Zhao Q., Zheng L., Zhong F., Zhong W., Zhu S., Zhao S., Gilbert D., Baumhueter S., Spier G., Carter C., Cravchik A., Woodage T., Ali F., An H., Awe A., Baldwin D., Baden H., Barnstead M., Barrow I., Beeson K., Busam D., Carver A., Center A., Cheng M. L., Curry L., Danaher S., Davenport L., Desilets R., Dietz S., Dodson K., Doup L., Ferriera S., Garg N., Gluecksmann A., Hart B., Haynes J., Haynes C., Heiner C., Hladun S., Hostin D., Houck J., Howland T., Ibegwam C., Johnson J., Kalush F., Kline L., Koduru S., Love A., Mann F., May D., McCawley S., McIntosh T., McMullen I., Moy M., Moy L., Murphy B., Nelson K., Pfannkoch C., Pratts E., Puri V., Qureshi H., Reardon M., Rodriguez R., Rogers Y. H., Romblad D., Ruhfel B., Scott R., Sitter C., Smallwood M., Stewart E., Strong R., Suh E., Thomas R., Tint N. N., Tse S., Vech C., Wang G., Wetter J., Williams S., Williams M., Windsor S., Winn-Deen E., Wolfe K., Zaveri J., Zaveri K., Abril J. F., Guigo R., Campbell M. J., Sjolander K. V., Karlak B., Kejariwal A., Mi H., Lazareva B., Hatton T., Narechania A., Diemer K., Muruganujan A., Guo N., Sato S., Bafna V., Istrail S., Lippert R., Schwartz R., Walenz B., Yooseph S., Allen D., Basu A., Baxendale J., Blick L., Caminha M., Carnes-Stine J., Caulk P., Chiang Y. H., Coyne M., Dahlke C., Mays A., Dombroski M., Donnelly M., Ely D., Esparham S., Fosler C., Gire H., Glanowski S., Glasser K., Glodek A., Gorokhov M., Graham K., Gropman B., Harris M., Heil J., Henderson S., Hoover J., Jennings D., Jordan C., Jordan J., Kasha J., Kagan L., Kraft C., Levitsky A., Lewis M., Liu X., Lopez J., Ma D., Majoros W., McDaniel J., Murphy S., Newman M., Nguyen T., Nguyen N., Nodell M., Pan S., Peck J., Peterson M., Rowe W., Sanders R., Scott J., Simpson M., Smith T., Sprague A., Stockwell T., Turner R., Venter E., Wang M., Wen M., Wu D., Wu M., Xia A., Zandieh A., Zhu X. The sequence of the human genome // Science.-2001.-291, N 5507.-P. 1304-1351.

60. Bird A. The essentials of DNA methylation // Cell.-1992.70, N 1.-P. 5-8.

61. Feng Q., Balasubramanian A., Hawes $S$. E., Toure P., Sow P. S., Dem A., Dembele B., Critchlow C. W., Xi L., Lu H., McIntosh M. W., Young A. M., Kiviat N. B. Detection of hypermethylated genes in women with and without cervical neoplasia // J. Nat. Cancer Inst.-2005.-97, N 4.-P. 273-282.

62. Kransdorf E. P., Wang S. Z., Zhu S. Z., Langston T. B., Rupon $J$. W., Ginder G. D. MBD2 is a critical component of a methyl cytosine-binding protein complex isolated from primary erythroid cells // Blood.-2006.-108, N 8.-P. 2836-2845.

63. Salozhin S. V., ProkhortchoukE. B., Georgiev G. P. Methylation of DNA - one of the major epigenetic markers // Biochemistry (Mosc.).-2005.-70, N 5.-P. 525-532. 
64. Kondo E., Gu Z., Horii A., Fukushige S. The thymine DNA glycosylase MBD4 represses transcription and is associated with methylated p16(INK4a) and hMLH1 genes // Mol. Cell Biol.-2005.-25, N 11.-P. 4388-4396.

65. Hattori M., Sakamoto H., Satoh K., Yamamoto T. DNA demethylase is expressed in ovarian cancers and the expression correlates with demethylation of $\mathrm{CpG}$ sites in the promoter region of c-erbB-2 and survivin genes // Cancer Lett.-2001.169, N 2.-P. 155-164.

66. Kanai Y., Ushijima S., Nakanishi Y., Hirohashi S. Reduced mRNA expression of the DNA demethylase, MBD2, in human colorectal and stomach cancers // Biochem. Biophys. Res. Communs.-1999.-264, N 3.-P. 962-966.

67. Baylin S. B., Herman J. G., Graff J. R., Vertino P. M., Issa J. $P$. Alterations in DNA methylation: a fundamental aspect of neoplasia // Adv. Cancer Res.-1998.-72.-P. 141-196.

68. Mummaneni P., Yates P., Simpson J., Rose J., Turker M. S. The primary function of a redundant $\mathrm{Sp} 1$ binding site in the mouse aprt gene promoter is to block epigenetic gene inactivation // Nucl. Acids Res.-1998.-26, N 22.-P. 5163-5169.

69. Lujambio A., Calin G. A., Villanueva A., Ropero S., SanchezCespedes M., Blanco D., Montuenga L. M., Rossi S., Nicoloso M. S., Faller W. J., Gallagher W. M., Eccles S. A., Croce C. M., Esteller $M$. A microRNA DNA methylation signature for human cancer metastasis // Proc. Nat. Acad. Sci. USA.2008.-105, N 36.-P. 13556-13561.

70. Szyf M. DNA methylation and demethylation as targets for anticancer therapy // Biochemistry (Mosc).-2005.-70, N 5.P. 533-549.

71. Ye F., Zhang S. F., Xie X., Lu W. G. OPCML gene promoter methylation and gene expression in tumor and stroma cells of invasive cervical carcinoma // Cancer Invest.-2008.-26, N 6.-P. 569-574.

72. Overmeer R. M., Henken F. E., Snijders P. J., Claassen-Kramer D., Berkhof J., Helmerhorst T. J., Heideman D. A., Wilting S. M., Murakami Y., Ito A., Meijer C. J., Steenbergen R. $D$. Association between dense CADM1 promoter methylation and reduced protein expression in high-grade CIN and cervical SCC // J. Pathol.-2008.-215, N 4.-P. 388-397.

73. Lee J., Yoon Y. S., Chung J. H. Epigenetic silencing of the WNT antagonist DICKKOPF-1 in cervical cancer cell lines // Gynecol. Oncol.-2008.-109,-N 2.-P. 270-274.

74. Lim S. L., Smith P., Syed N., Coens C., Wong H., van der Burg M., Szlosarek P., Crook T., Green J. A. Promoter hypermethylation of FANCF and outcome in advanced ovarian cancer // Br. J. Cancer.-2008.-98, N 8.-P. 1452-1456.

75. Mhawech P., Benz A., Cerato C., Greloz V., Assaly M., Desmond J. C., Koeffler H. P., Lodygin D., Hermeking H., Herrmann F., Schwaller J. Downregulation of 14-3-3sigma in ovary, prostate and endometrial carcinomas is associated with CpG island methylation // Mod. Pathol.-2005.-18, N 3.P. 340-348.

76. Feng W., Marquez R. T., Lu Z., Liu J., Lu K. H., Issa J. P., Fishman D. M., Yu Y., Bast R. C. Jr. Imprinted tumor suppressor genes ARHI and PEG3 are the most frequently downregulated in human ovarian cancers by loss of heterozygosity and promoter methylation // Cancer.-2008.-112, N 7.P. 1489-1502.

77. Chen H., Ye F., Zhang J., Lu W., Cheng Q., Xie X. Loss of OPCML expression and the correlation with $\mathrm{CpG}$ island methylation and $\mathrm{LOH}$ in ovarian serous carcinoma // Eur. J. Gynaecol. Oncol.-2007.-28, N 6.-P. 464-467.

78. Teodoridis J. M., Hall J., Marsh S., Kannall H. D., Smyth C., Curto J., Siddiqui N., Gabra H., McLeod H. L., Strathdee G., Brown R. CpG island methylation of DNA damage response genes in advanced ovarian cancer // Cancer Res.-2005.-65, N 19.-P. 8961-8967.

79. Kwong J., Lee J. Y., Wong K. K., Zhou X., Wong D. T., Lo K. W., Welch W. R., Berkowitz R. S., Mok S. C. Candidate tumor-suppressor gene DLEC 1 is frequently downregulated by promoter hypermethylation and histone hypoacetylation in human epithelial ovarian cancer // Neoplasia.-2006.-8, N 4.P. 268-278.

80. Agathanggelou A., Honorio S., Macartney D. P., Martinez A., Dallol A., Rader J., Fullwood P., Chauhan A., Walker R., Shaw J. A., Hosoe S., Lerman M. I., Minna J. D., Maher E. R., Latif $F$. Methylation associated inactivation of RASSF1A from region 3 p21.3 in lung, breast and ovarian tumours // Oncogene.-2001.-20, N 12.-P. 1509-1518.

81. Maat W., Ly L. V., Jordanova E. S., de Wolff-Rouendaal D., Schalij-Delfos N. E., Jager M. J. Monosomy of chromosome 3 and an inflammatory phenotype occur together in uveal melanoma // Invest. Ophthalmol. Vis. Sci.-2008.-49, N 2.P. 505-510.

82. Vidaurreta M., Maestro M. L., Sanz-Casla M. T., Maestro C., Rafael S., Veganzones S., Moreno J., Blanco J., Silmi A., Arroyo $M$. Inactivation of $\mathrm{p} 16$ by $\mathrm{CpG}$ hypermethylation in renal cell carcinoma // Urol. Oncol.-2008.-26, N 3.-P. 239245.

83. Majid S., Dar A. A., Shahryari V., Hirata H., Ahmad A., Saini S., Tanaka Y., Dahiya A. V., Dahiya R. Genistein reverses hypermethylation and induces active histone modifications in tumor suppressor gene B-Cell translocation gene 3 in prostate cancer // Cancer.-2010.-116, N1.-P. 66-76.

84. Majid S., Dar A. A., Ahmad A. E., Hirata H., Kawakami K., Shahryari V., Saini S., Tanaka Y., Dahiya A. V., Khatri G., Dahiya $R$. BTG3 tumor suppressor gene promoter demethylation, histone modification and cell cycle arrest by genistein in renal cancer // Carcinogenesis.-2009-30, N 4.-P. 662670.

85. Lu T. Y., Kao C. F., Lin C. T., Huang D. Y., Chiu C. Y., Huang $Y$. S., Wu H. C. DNA methylation and histone modification regulate silencing of OPG during tumor progression // J. Cell Biochem.-2009.-108, N 1.-P. 315-325.

86. Kaneuchi M., Sasaki M., Tanaka Y., Shiina H., Verma M., Ebina Y., Nomura E., Yamamoto R., Sakuragi N., Dahiya R. Expression and methylation status of 14-3-3 sigma gene can characterize the different histological features of ovarian cancer // Biochem. Biophys. Res. Communs.-2004.-316, N 4.P. $1156-1162$.

87. Terasawa K., Sagae S., Toyota M., Tsukada K., Ogi K., Satoh A., Mita H., Imai K., Tokino T., Kudo R. Epigenetic inactivation of TMS1/ASC in ovarian cancer // Clin. Cancer Res.2004.-10, N 6.-P. 2000-2006.

88. Kaneuchi M., Sasaki M., Tanaka Y., Shiina H., Yamada H., Yamamoto R., Sakuragi N., Enokida H., Verma M., Dahiya R. WT1 and WT1-AS genes are inactivated by promoter methylation in ovarian clear cell adenocarcinoma // Cancer.-2005.104, N 9.-P. 1924-1930.

89. Makarla P. B., Saboorian M. H., Ashfaq R., Toyooka K. O., Toyooka S., Minna J. D., Gazdar A. F., Schorge J. O. Promoter hypermethylation profile of ovarian epithelial neoplasms // Clin. Cancer Res.-2005.-11, N 15.-P. 5365-5369.

90. Richiardi L., Fiano V., Vizzini L., De Marco L., Delsedime L., Akre O., Tos A. G., Merletti F. Promoter methylation in APC, RUNX3, and GSTP1 and mortality in prostate cancer patients // J. Clin. Oncol.-2009.-27, N 19.-P. 3161-3168.

91. Wilson A. S., Power B. E., Molloy P. L. DNA hypomethylation and human diseases // Biochim. Biophys. Acta.-2007.1775, N 1.-P. 138-162. 
92. Ehrlich $M$. DNA methylation and cancer-associated genetic instability // Adv. Exp. Med. Biol.-2005.-570. -P. 363-392.

93. Del Senno L., Maestri I., Piva R., Hanau S., Reggiani A., Romano A., Russo G. Differential hypomethylation of the c-myc protooncogene in bladder cancers at different stages and grades // J. Urol.-1989.-142, N 1.-P. 146-149.

94. Izutsu N., Maesawa C., Shibazaki M., Oikawa H., Shoji T., Sugiyama T., Masuda T. Epigenetic modification is involved in aberrant expression of class III beta-tubulin, TUBB3, in ovarian cancer cells // Int. J. Oncol.-2008.-32, N 6.-P. 12271235.

95. Rose S. L., Fitzgerald M. P., White N. O., Hitchler M. J., Futscher B. W., De Geest K., Domann F. E. Epigenetic regulation of maspin expression in human ovarian carcinoma cells // Gynecol. Oncol.-2006.-102, N 2.-P. 319-324.

96. Czekierdowski A., Czekierdowska S., Wielgos M., Smolen A., Kaminski P., Kotarski J. The role of CpG islands hypomethylation and abnormal expression of neuronal protein synuclein-gamma (SNCG) in ovarian cancer// Neuro Endocrinol. Lett.-2006.-27, N 3.-P. 381-386.

97. Litkouhi B., Kwong J., Lo C. M., Smedley J. G. 3rd., McClane B. A., Aponte M., Gao Z., Sarno J. L., Hinners J., Welch W. R., Berkowitz R. S., Mok S. C., Garner E. I. Claudin-4 overexp- ression in epithelial ovarian cancer is associated with hypomethylation and is a potential target for modulation of tight junction barrier function using a C-terminal fragment of Clostridium perfringens enterotoxin // Neoplasia.-2007.-9, N 4.-P. 304-314.

98. Florl A. R., Lower R., Schmitz-Drager B. J., Schulz W. A. DNA methylation and expression of LINE-1 and HERV-K provirus sequences in urothelial and renal cell carcinomas // Br. J. Cancer.-1999.-80, N 9.-P. 1312-1321.

99. Widschwendter M., Siegmund K. D., Muller H. M., Fiegl H., Marth C., Muller-Holzner E., Jones P. A., Laird P. W. Association of breast cancer DNA methylation profiles with hormone receptor status and response to tamoxifen // Cancer Res.-2004.-64, N 11.-P. 3807-3813.

100. Poleshko A., Einarson M. B., Shalginskikh N., Zhang R., Adams P. D., Skalka A. M., Katz R. A. Identification of a functional network of human epigenetic silencing factors // J. Biol. Chem.-2010.-285, N 1.-P. 422-433.

UDC 577.218; 616.006 .6 Received 17.12.09 